\title{
Effect of different extraction process on skin gelatin from Talang queenfish (Scomberoides commersonnianus)
}

\author{
Akshay R. Akhade ${ }^{1}$, Jayappa M. Koli*1, Surendra B. Patange ${ }^{2}$, Mangesh M. Shirdhankar ${ }^{3}$ and Ashish S. \\ Mohite ${ }^{1}$ \\ ${ }^{1}$ College of Fisheries, Ratnagiri (M.S.) India \\ ${ }^{2}$ Post Graduate Institute, Post-Harvest Management, Roha, Raigad (M.S.) India \\ ${ }^{3}$ Diploma in Fisheries Engineering, Ratnagiri (M.S.) India \\ Email : adithramesh10@gmail.com \\ *Author for Correspondence \\ Research chronicle : Received : 25.10.2019; Revised : 15.11.2019; Accepted : 28.11.2019
}

\section{SUMMARY :}

In the fish processing industry generated waste during filleting of Talang queenfish (Scomberoides commersonnianus) was utilized for gelatin extraction in the present investigation. These waste materials being rich in collagen are valuable raw materials for gelatin extraction. The fish skin was used for gelatin extraction by ten different methods as described by different authors namely, Grossman and Bergman (1992), Gudmundsson and Hafsteinsson (1997), Gomez-Guillen and Montero (2001), Gimenez et al. (2005), Zhou and Regenstein (2005), Kolodziejska et al. (2008), Liu et al. (2008), Rahman et al. (2008), Benjakul et al. (2009) and Barve (2012). The results of yield were varied between 4.12 to $12.83 \%$ and gel strength was varied in between 162.51 to $226.11 \mathrm{~g}$. Based on the yield and gel strength of extracted gelatins, the method of Barve (2012) was found the best method. This method revealed that yield and gel strength were $12.83 \%$ and $226.11 \mathrm{~g}$, respectively and found significantly different comparatively other methods.

KEY WORDS : Talang queenfish, Fish skin, Gelatin, Extraction process, Yield, Gel strength

How to cite this paper : Akhade, Akshay R., Koli, Jayappa M., Patange, Surendra B., Shirdhankar, Mangesh M. and Mohite, Ashish S. (2019). Effect of different extraction process on skin gelatin from Talang queenfish (Scomberoides commersonnianus). Internat. J. Proc. \& Post Harvest Technol., 10(2) : 35-42. DOI: 10. 15740/ HAS/IJPPHT/10.2/35-42. Copyright@ 2019: Hind Agri-Horticultural Society. 